\title{
Prevalence of Febrile Syndromes in Dengue Surveillance, Havana City, 2007
}

\author{
Otto Peláez MD, Lizet Sánchez MPH PhD, Pedro Más MD PhD DrSc, Suzette Pérez MD MS, Gustavo Kourí MD PhD DrSc, \\ María G. Guzmán MD PhD DrSc
}

Translated from the Spanish and reprinted with permission from the Revista Cubana de Higiene y Epidemiología, Vol 48 No 18 , Jan-Apr 2010. Original available at: http://bvs.sld.cu/revistas/hie/vol_48_1_10/hie02110.htm

\begin{abstract}
OBJECTIVE Determine point prevalence of febrile syndromes and compare with prevalence reported by habitual clinical and seroepidemiologic dengue surveillance system in Havana City.

METHODS In October 2007, a descriptive, cross-sectional study was carried out in a representative sample, calculating prevalences of febrile syndromes and undifferentiated febrile syndromes Chi-square analysis was used for rate comparisons.

RESULTS Point prevalences of febrile syndromes and undifferentiated febrile syndromes were 352.6 and 144.2 times greater respectively, than those reported by the habitual clinical and seroepidemiologic dengue surveillance system; these differences were statistically significant $(p<0.001)$
\end{abstract}

CONCLUSIONS Point prevalence of febrile syndromes was far greater than prevalence reported by the habitual clinical and seroepidemiologic dengue surveillance system, an indication of underreporting.

KEYWORDS fever, undifferentiated fever, dengue, dengue fever, dengue/epidemiology, seroepidemiologic studies, Cuba

\section{INTRODUCTION}

Dengue is an acute viral disease caused by the virus of the same name, which has four serotypes (dengue 1, 2, 3, and 4). It is transmitted to humans by the Aedes aegypti mosquito, its primary vector. Among arthropod-transmitted viral diseases, dengue is currently the most important and is a public health priority for tropical and subtropical countries. The Americas region is one of the most severely affected by dengue fever and dengue hemorrhagic fever (DHF).[1]

Weakened public health systems and lack of sustainable vector control programs in this region have made dengue endemic[2] to all countries in Latin America except Chile, Uruguay, and Cuba.[3]

Control efforts during the most recent dengue outbreaks in Cuba demonstrated the risk of a dengue epidemic, even with a wellestablished surveillance and control program. Yet it has been shown that if PAHO and $\mathrm{WHO}$ dengue-control principles are adequately implemented, transmission can be eliminated and dengue endemicity prevented.[4]

The four main pillars of dengue surveillance are clinical observation, epidemiology, entomology, and virology. The objective is to expeditiously locate, report, and confirm clinically-suspected cases.[5] Presence of a suspected case triggers intensive, active surveillance and control involving participation by the health sector as well as communities themselves.[6]
In Cuba, clinical seroepidemiologic surveillance of dengue is carried out at the primary care level, based on detection and follow-up of acute febrile syndrome cases of undetermined etiology (Cruz Oramas G. Estratificación del riesgo de introducción y trasmisión del dengue en el municipio Playa. Tesis de Máster en Epidemiología. Ciudad de La Habana, Instituto de Medicina Tropical Pedro Kourí; 2000).

Active clinical and epidemiological surveillance are fundamental to early detection of transmission and to follow-up and study of epidemic outbreaks.[7]

Detection of a suspected case activates the health system to intensify the search for febrile syndrome (FS), undifferentiated febrile syndrome (UFS), and other cases where there is a clinical suspicion of dengue; blood samples are collected from people in the latter group six days after onset of symptoms for laboratory confirmation by screening for dengue IgM.[6]

Since 1997, Havana City has maintained a solid clinical seroepidemiologic surveillance system for dengue, enabling early identification of disease transmission, as well as actions aimed at source control when imported dengue cases appear.[At the time this article was published, Havana City was a province with fifteen municipalities.-Ed.]

Fever reports phoned in to the Direct Information System (SID, its Spanish acronym) are monitored daily (Ministerio de Salud Pública. Higiene y Epidemiología. Sistema de Información Directa, SID. 1982). These reports fluctuate depending on the epidemiologic situation and other factors related to health system activation levels (Peláez O. Vigilancia del dengue 2001-2002. Presented at the International Public Health Convention 2002. Havana, 4 May 2002).

A time-series analysis of FS in Havana City from 1997 to 2006[8] showed daily average reporting rates ranging from 2.1 to 6.4 per 100,000 population, with large variations according to municipality, time of year, and health system activation level, the last depending on the specific epidemiologic situation at the time. Given that dengue is not endemic to Cuba, there is no local experience, nor reports in the international literature reviewed, to estimate expected daily FS prevalence and how many of these cases could be considered UFS, to be studied as "suspected dengue" in the clinical seroepidemiologic surveillance program (SID, previously cited).

Thus, our research for this paper was conducted to estimate FS prevalence in Havana City, as well as to describe FS management, with the aim of contributing to dengue surveillance quality improvement. 


\section{METHODS}

A cross-sectional (prevalence) study was designed, in which the 15 municipalities of Havana City province were represented. The study universe was comprised of the province's total population $(2,185,892$ inhabitants), who live in 744,467 dwellings distributed over 13,410 city blocks.

Multistage equiprobabilistic cluster sampling was done, with individuals as the study units. Epi Info 2000 version 3.2 statistical software was used to estimate sample size, based on an expected prevalence of $0.01 \%$, a maximum permissible error of $5 \%$, and an estimated population of 2,185,892 inhabitants in the study area, according to the National Statistics Bureau. The minimum sample size necessary for this study was 1535 persons.

For all individuals to have the same selection probability, the sample was distributed among geographic areas proportional to the percentage of the provincial population living in each.

Study participants were individuals who regularly resided in the selected households and who had been physically present there at some point during the seven days preceding the visit; they were included in the study until the sample size for each city block was reached. Information was collected using a questionnaire administered to participants by the study's 28 interviewers-one per block; all staff at the Provincial Hygiene and Epidemiology Center.

FS was identified when the individual reported to body temperature above $37^{\circ} \mathrm{C}$ at some point during the 24 hours prior to the interview, or when confirmed during the interviewer visit, regardless of number of days or possible cause. If, after the first six days of evolution, fever was unexplained by clinical diagnosis, then the case was considered undifferentiated febrile syndrome (UFS) or acute febrile syndrome of undetermined etiology.

As defined by PAHO, a suspected dengue case, involves acute febrile illness coupled with two or more of the following: headache, retro-orbital pain, myalgia, arthralgia, rash, hemorrhagic manifestations, and leucopenia.

Information was collected simultaneously from all city blocks included in the study on Saturday, 20 October 2007, corresponding to Epidemiological Week 42. This week was chosen because the Provincial Health Department Statistics Bureau indicates its FS reports were the historical average over time series for 1997 to 2006.[8] Saturday was chosen because of the probability of finding more residents at home and so that the survey would not interfere with interviewers' weekday work schedule.

An interviewer visited each household, filled out the corresponding survey form, and submitted it to the principal investigator on the following Monday, after reviewing the quality of information collected. The same afternoon, a meeting was held with the heads of the [Ministry of Public Health's] International Disease Control Program in the province's 15 municipalities. They were given the survey forms for households where persons with fever were located, with instructions to ensure follow-up visits on the sixth day from onset of fever, to determine if a clinical diagnosis had been made. Serological tests using the Ultra Micro Analytic System (SUMA, its Spanish acronym) were performed when UFS persisted or there was clinical suspicion of dengue.
UMELISA dengue IgM plus is a commercial test developed and produced by the Immunoassay Center (CIE, its Spanish acronym) in Havana, Cuba based on SUMA technology, ...[able to] detect the four dengue virus serotypes. This is the established screening technique used by the dengue epidemiological surveillance system, demonstrating high sensitivity (99.4\%) and specificity $(94.8 \%)$. Cases testing positive with SUMA are confirmed in the National Reference Laboratory at the Pedro Kourí Tropical Medicine Institute using the ELISA IgM capture method developed there.[9]

One week later, all survey forms were collected; and the principal investigator verified at the Provincial Hygiene and Epidemiology Center, whether its laboratory had carried out the dengue IgM tests, and obtained their results.

Data from questionnaires were entered into an Epi Info 2000 version 3.2 database; results were presented in tables.

A frequency analysis of study variables was conducted. FS and UFS point prevalences were also calculated for each municipality and a chi-square $\left(X^{2}\right)$ test performed to compare the study's estimated prevalence with that found by the regular surveillance system, based on SID reports compiled for the same day. Frequencies and percentages were estimated for fever cases studied, with a $95 \%$ confidence interval.

Training for the health workers who participated in the study included an explanation of the study's importance, stressing its benefits for the health of the province's inhabitants, contributing to a deeper understanding of the functioning of the clinical seroepidemiologic surveillance system for dengue. The questionnaire included written informed consent, and participants were informed that their confidentiality would be respected, making it clear that participation would result in no detriment to them or their family members.

\section{RESULTS}

A total of 1814 persons were surveyed, 105.3[\%] of the minimum required sample size. The largest age group was 25 to 49 years old $(40.5 \%$ of total), followed by those aged $<15$ years $(18 \%), 15$ to 24 years $(15.7 \%)$ and 50 to 64 years $(14.6 \%)$ and $\geq 65$ years $(11.2 \%)$.

The majority of respondents $(55.2 \%)$ were women. The sample was representative of the provincial population in age group distribution $(p<0.30)$ and sex $(p=0.06)$, according to the 2002 population and housing census (Oficina Nacional de Estadísticas. Informe Nacional Censo de Población y Viviendas. Cuba. 2002. ONE; 2005).

A total of 26 febrile persons were found in the homes visited. Every municipality had at least one person with fever. Table 1 shows the FS frequency and point prevalence by municipality. Point prevalence in the province was 1433.3 per 100,000 population.

On day six following onset of symptoms, eight people with fever had no clinical diagnosis and therefore were considered cases of UFS, a point prevalence for the province of 441.0 per 100,000 population.

Table 2 summarizes the differences between FS and UFS point prevalence and prevalence reported by the regular dengue clinical 
seroepidemiologic surveillance system. For FS, point prevalence was 352.6 times greater, and for UFS, 144.2 times greater-both statistically significant differences $(p<0.001)$.

All cases of fever were identified during the first five days of clinical evolution; $53.8 \%$ in the first 24 hours from symptom onset.

Table 1. Frequency and point prevalence of febrile syndrome (FS) by municipality, Havana City Province, 2007

\begin{tabular}{|l|r|r|r|}
\hline Municipality & $\begin{array}{r}\text { FS } \\
\text { Frequency }\end{array}$ & $\begin{array}{c}\text { FS Point } \\
\text { Prevalence* }\end{array}$ & $\begin{array}{c}\text { Confidence } \\
\text { Interval }\end{array}$ \\
\hline Playa & 3 & 2713.9 & $2143.5-2204.3$ \\
\hline Plaza & 2 & 1754.4 & $1724.5-1784.3$ \\
\hline Centro Habana & 1 & 819.7 & $806.5-832.8$ \\
\hline Habana Vieja & 1 & 1428.6 & $1388.6-1468.5$ \\
\hline Regla & 1 & 2631.6 & $2496.0-2767.2$ \\
\hline Habana del Este & 4 & 2469.1 & $2439.8-2498.4$ \\
\hline Guanabacoa & 4 & 4651.2 & $4549.0-4753.3$ \\
\hline San Miguel del & 1 & 714.3 & $704.3-724.3$ \\
\hline Padrón & 1 & 463.0 & $458.8-467.2$ \\
\hline 10 de Octubre & 1 & 819.7 & $806.5-832.8$ \\
\hline Cerro & 1 & 900.9 & $885.0-9146.8$ \\
\hline Marianao & 1 & 833.3 & $819.7-846.9$ \\
\hline Lisa & 1 & 1449.3 & $1428.9-1469.7$ \\
\hline Boyeros & 2 & 574.7 & $568.2-581.2$ \\
\hline Arroyo Naranjo & 1 & 3174.6 & $3077.5-3271.7$ \\
\hline Cotorro & 2 & 1433.3 & $1431.8-1434.8$ \\
\hline Province & 26 & &
\end{tabular}

*Per 100,000 population

Source: Febrile Syndrome Prevalence Survey
All those with fever had at least one accompanying sign or symptom, predominantly respiratory symptoms $(53.8 \%)$, followed by headache $(46.2 \%)$, weakness $(38.5 \%)$, and anorexia $(30.5 \%)$.

Of those who had fever for over six days, 18 (69.2\%), had received a clinical diagnosis that accounted for the fever (16 with acute respiratory infections and two with acute urinary infections). Eight patients (30.8\%) continued with a diagnosis of UFS.

Among those with UFS, $87.5 \%$ were aged 5 to 14 years, equally divided between the sexes. Symptoms accompanying fever were weakness $(87.5 \%)$, headache $(75.0 \%)$, and anorexia $(62.5 \%)$. None met clinical criteria for suspected dengue cases. All were found during the first three days from symptom onset, and half within the first 24 hours. All those with UFS were tested on the sixth day after onset of symptoms, using serology to test for dengue IgM. All were negative.

\section{DISCUSSION}

This study was a preliminary exploration to learn more about the functioning of the clinical seroepidemiologic surveillance system for dengue in Havana City. It confirms a high prevalence of FS and UFS, several times greater than that reported by the regular notification system.

Acute respiratory infection was the most frequent diagnosis in those with fever. Once six days had passed from onset of symptoms, almost one-third of those with fever still did not have a firm diagnosis and could be considered cases of UFS and candidates for serological study for presence of dengue IgM. This was performed in all cases, with negative results.
Table 2: Study and surveillance system prevalences of febrile syndrome (FS) and undifferentiated febrile syndrome (UFS), Havana City Province, 2007

\begin{tabular}{|c|c|c|c|c|c|c|}
\hline \multirow[b]{2}{*}{ Municipality } & \multicolumn{2}{|c|}{ Study Survey } & \multicolumn{2}{|c|}{ Surveillance System } & \multicolumn{2}{|c|}{ Odds Ratio } \\
\hline & $\begin{array}{c}\text { FS } \\
\text { Prevalence* }^{*}\end{array}$ & \begin{tabular}{|c|} 
UFS \\
Prevalence $^{*}$
\end{tabular} & $\begin{array}{c}\text { FS } \\
\text { Prevalence* }^{*}\end{array}$ & $\begin{array}{c}\text { UFS } \\
\text { Prevalence* }^{*}\end{array}$ & FS & UFS \\
\hline Playa & 2173.9 & 0.0 & 1.8 & 2.5 & 1177.9 & 0.0 \\
\hline Plaza & 1754.4 & 0.0 & 0.4 & 1.0 & 4929.7 & 0.0 \\
\hline $\begin{array}{l}\text { Centro } \\
\text { Habana }\end{array}$ & 819.7 & 819.7 & 4.0 & 1.9 & 204.8 & 429.1 \\
\hline $\begin{array}{l}\text { Habana } \\
\text { Vieja }\end{array}$ & 1428.6 & 0.0 & 6.4 & 2.0 & 224.9 & 0.0 \\
\hline Regla & 2631.6 & 2631.6 & 2.6 & 1.3 & 1018.3 & 2036.6 \\
\hline $\begin{array}{l}\text { Habana } \\
\text { del Este }\end{array}$ & 2469.1 & 1851.9 & 7.9 & 4.2 & 312.4 & 441.6 \\
\hline Guanabacoa & 4651.2 & 0.0 & 5.1 & 3.8 & 917.7 & 0.0 \\
\hline $\begin{array}{l}\text { San Miguel } \\
\text { del Padrón }\end{array}$ & 714.3 & 0.0 & 3.3 & 3.1 & 214.4 & 0.0 \\
\hline $\begin{array}{l}10 \text { de } \\
\text { Octubre }\end{array}$ & 463.0 & 463.0 & 3.5 & 2.3 & 130.5 & 203.0 \\
\hline Cerro & 819.7 & 0.0 & 9.1 & 4.6 & 89.9 & 0.0 \\
\hline Marianao & 900.9 & 900.9 & 5.7 & 6.7 & 157.7 & 135.2 \\
\hline Lisa & 833.3 & 833.3 & 6.4 & 5.9 & 129.4 & 141.4 \\
\hline Boyeros & 1449.3 & 0.0 & 1.4 & 2.3 & 1059.1 & 0.0 \\
\hline $\begin{array}{l}\text { Arroyo } \\
\text { Naranjo }\end{array}$ & 574.7 & 0.0 & 2.4 & 2.4 & 241.0 & 0.0 \\
\hline Cotorro & 3174.6 & 0.0 & 3.6 & 1.7 & 871.3 & 0.0 \\
\hline Province & 1433.3 & 441.0 & 4.1 & 3.1 & 352.6 & 144.2 \\
\hline
\end{tabular}

*Per 100,000 population

Source: Direct Information System, Provincial Health Department and Febrile Syndrome Prevalence Survey
These research results can be considered reliable, given continuous observation of participants with FS, triangulation of the techniques used (interview and observation), and monitoring of study participants.

Selection bias was controlled for by use of random sampling, and information bias[10] was controlled for by validating the survey instrument and training interviewers in advance.

In the literature reviewed, we did not find similar studies of fever prevalence to compare with our results. However, the limits of surveillance systems have been addressed concerning their ability to ascertain real prevalence of events monitored, in particular of illnesses or events with high incidence and low severity, which are under-reported, leading to undercounting.[11] Logically, this under-reporting affects sensitivity and, therefore, the surveillance system, which then calls for the system's external validation to learn the prevalence of an event in the community. Crosssectional studies are an excellent way to-as much as possible-compare 
behavior of traditional event reporting with study results using the system's regular information collection,[12] to correct errors.

According to Pelluci and Barboza (2006), the validity of dengue surveillance systems depends directly on the quality of data collected. In an evaluation of an information collection system, they found undercounting, more pronounced during interepidemic periods.[13]

The marked undercounting found in this study is derived from the surveillance system's low sensitivity to identification and reporting of all patients with fever, even at a time when it was assumed the system would be on maximum alert due to [dengue] transmission in one of the province's municipalities.

Among other things, this could be explained by health personnel's low risk perception of re-introduction of dengue into the country; ignorance of the importance of follow-up and study of FS cases; monotony in clinical practice due to the fact that most results are negative; lack of endemic virus circulation; and, finally, administrative pressures triggered by an FS case report, which, depending on the epidemiological situation at the time, implies consistent follow-up, home care or hospital admission.

Several authors have investigated the usefulness of FS studies for early diagnosis of a dengue epidemic outbreak,[14] and the limits of clinical definitions for identification of dengue cases. [15-17] Martínez et al. (2006) studied the difficulty in early clinical diagnosis of dengue in endemic areas and the impact of this on initial medical management. They stress the importance of early detection of patients with fever, using evidence from physical examination to exclude those with a source of infection other than dengue.[18]

In our setting, where dengue is not endemic and FS detection is done actively (depending on the epidemiological situation), an at- tempt is made to identify febrile patients as close as possible to symptom onset, when, for obvious reasons, the clinical picture is not well defined. This, in turn, is why no case of fever should be ruled out (unless there is a clear diagnosis justifying it). Indication is for these FS cases to be followed to the sixth day after symptom onset to determine which continue as UFS or suspected dengue cases, in which case they are to be studied using serology to test for dengue IgM (SID, cited above).[3] This concurs with our results, even though none of the UFS cases met the definition of a suspected case, a high number did meet the criteria for serological study for dengue IgM, as part of the surveillance system (Peláez O, cited above).[7]

Other studies have developed diagnostic models to differentiate dengue from other FS causes, and have pointed out that although respiratory symptoms are not part of the conventional clinical description of dengue, they may be present infrequently. $[19,20]$ Several investigators have found that headache, myalgia, and arthralgia were very frequent in dengue patients, but that the specificity of these symptoms was below $20 \%$. It was also found that almost half of patients studied had different causes of febrile illness with clinical manifestations similar to those of dengue, without significant differences. $[17,21,22]$ As in our study, these studies found that acute respiratory infections to be the most frequent cause of UFS in several regions of the world.[23-25]

In Cuba, acute respiratory infections are also important contributors to morbidity and hospitalizations, and are the primary reason for outpatient visits. (Cuba. Ministerio de Salud Pública. Dirección Nacional de Epidemiología. Programa Nacional Integral de Control de las Infecciones Respiratorias Agudas, IRA. 2000). Furthermore, consistent with the endemic channel for respiratory infections, they were at their epidemic peak at the time of the survey,[26] explaining [this part of] our results. -1 .

\section{REFERENCES}

1. Guzmán MG, García G, Kourí G. El dengue y el dengue hemorrágico: prioridades de investigación. Rev Panam Salud Pública 2006;19(3):204-13.

2. Gubler DJ. The changing epidemiology of yellow fever and dengue, 1900 to 2003 full circle. Comp Immunol Microbiol Infect Dis 2004;27:319-30.

3. Kourí G. El dengue, un problema creciente de salud en Las Américas. Rev Panam Salud Pública 2006;19(3):143-45.

4. Guzmán MG, Peláez O, Kourí G, Quintana I, Vázquez S, Pentón $M$, et al. Caracterización final y lecciones de la epidemia de dengue 3 en Cuba, 2001-2002. Rev Panam Salud Pública 2006;19(4):282-9.

5. Organización Panamericana de la Salud. Nueva generación de programas de prevención y control del Dengue en las Américas. Washington, D.C.: OPS; 2002 (PPS/HCP/HCT/206/02).

6. PAHO. Dengue and Dengue Hemorrhagic fever in the Americas: Guidelines for prevention and control. Washington, D.C.: PAHO;1994. (Scientific publication No. 548)

7. Peláez O, Guzmán M, Kourí G, Pérez R, San Martín J, Vázquez S, et. al. Dengue 3 epidemic, Havana, 2001. Emerging Infectious Diseases. [serial on the Internet] 2004 April [cited Nov 2009];10(4):719-22. Available from:http://www. cdc.gov/ncidod/EID/vol10no4/pdfs/03-0271.pdf.
8. Cuba. Ministerio de Salud Pública. Dirección Provincial de Salud de Cuidad de La Habana. Anuario Estadístico. Serie cronológica de síndromes febriles. 1996-2007.

9. Vázquez S, Valdivia I, Sánchez A, Calzada N, Guzmán MG. Evaluación del sistema diagnóstico UMELISA Dengue IgM plus. Archivos Venezolanos de Medicina Tropical 2007;5(1):4-18.

10. Hernández-Ávila M, Garrido F, Salazar-Martínez E. Sesgos en estudios epidemiológicos. Rev Salud Pública México 2000;42(5):438-46.

11. De Mateo S, Regidor E. Sistema de vigilancia de salud pública: no pidamos peras al holmo. Gac Sanit Barcelona 2003:17(4):1-7.

12. Batista R, González E. Evaluación de la vigilancia en atención primaria de salud: una propuesta metodológica. Rev Cubana Med Trop 2000;52(1):55-65

13. Pelluci H, Barboza E. Qualidade dos dados da vigilancia epidemiológica da dengue em Bello Horizonte. Rev Saude Pública 2006;40(1):1-11.

14. Organización Panamericana de la Salud. Definiciones de casos. Dengue. Boletín Epidemiológico. 2000;21:14-5

15. Wilder-Smith A, Schwartz E. Dengue in travelers. N Engl J Med 2005;353:924-32.

16. Díaz FA, Martínez RA, Villar LA. Indicadores tempranos de gravedad en el dengue. Enferm Infecc Microbiol Clin 2005;23:529-32.
17. Díaz FA, Villar LA, Martínez RA. Indicadores tempranos de infección por dengue en niños. An Pediatr (Barc) 2006;64(6):523-9.

18. Martínez RA, Díaz FA, Villar LA. Dificultad para el diagnóstico clínico temprano del dengue en un área endémica y su impacto sobre el manejo médico inicial. Rev Med Chile 2006;134(9):9.

19. Chadwick D, Arch B, Wilder-Smith A, Paton N Distinguishing dengue fever from other infections on the basis of simple clinical and laboratory features: Application of logistic regresión analysis. J Clin Virol 2006;35:147-53.

20. Díaz FA, Martínez RA, Villar LA. Criterios clínicos para diagnosticar el dengue en los primeros días de enfermedad. Biomédica 2006;26:22-30.

21. Rodríguez MB, Freire HB, Correa PR, Mendonca $M L$, Silva MR, Franca EB. Is it possible to identify dengue in children on the basis of Ministry of Health criteria for suspected dengue cases? J Pediatr 2005;81:209-15.

22. Phuong CX, Nhan NT, Kneen R, Thuy PT, van Thien C, Nga NT, et al. Clinical diagnosis and assessment of severity of confirmed dengue infections in Vietnamese children: Is the World Health Organization classification system helpful? Am J Trop Med Hyg 2004;70:172-9.

23. Silarug N, Foy HM, Kupradinon S, Rojanasuphot $S$, Nisalak A, Pongsuwant Y. Epidemic of fever of unknown origin in ruralThailand, caused by in- 
fluenza A (H1N1) and dengue fever. Southeast Asian J Trop Med Public Health 1990;21:61-7.

24. Instituto Nacional de Salud de Colombia, Ministerio de Salud. Epidemia de influenza/H3N2/ Beijing/32/92 en Ambalema, Tolima, 1994. Inf Quinc Epidemiol Nac 1996;1:6-8.

25. Torres $Y$, Mayca JA, Llanos LF, Velásquez JE, Capristano $S$. Virus influenza y el diagnóstico diferencial de sintomáticos febriles en la costa norte el Perú. Rev Perú Med Exp Salud Púb 2004;21(1):12-17.

26. Centro Provincial de Higiene y Epidemiología Unidad de Análisis y Tendencias en Salud. Boletín Anual. Ciudad de La Habana; 2007.

\section{THE AUTHORS}

Otto Peláez, physician specializing in epidemiology, Pedro Kourí Tropical Medicine
Institute, PAHO/WHO Collaborating Center for the Study and Control of Dengue, Havana, Cuba.

Lizet Sánchez, Instructor and associate researcher at Pedro Kourí Tropical Medicine Institute, Havana, with a bachelor's degree in mathematics, a master's degree in epidemiology and a doctorate in health sciences.

Pedro Más Bermejo, physician specializing in epidemiology, Pedro Kourí Tropical Medicine Institute, PAHO/WHO Collaborating Center for the Study and Control of Dengue, Havana, Cuba.
Suzette Pérez, physician specializing in epidemiology, Provincial Hygiene and Epidemiology Center, Havana, Cuba.

Gustavo Kourí, Founding Director, Pedro Kourí Tropical Medicine Institute, $\mathrm{PAHO} /$ WHO Collaborating Center for the Study and Control of Dengue, Havana, Cuba.

María G. Guzmán, distinguished researcher, and full professor, Pedro Kourí Tropical Medicine Institute, PAHO/WHO Collaborating Center for the Study and Control of Dengue, Havana, Cuba. 